\title{
SOUTH AFRICAN NURSING COUNCIL
}

EXAMINATIONS

\section{PROFESSIONAL SECTION - S.A. NURSING COUNCIL}

\section{OPSOMMING}

Die Suid-Afrikaanse Raad op Verpleging neem reeds sedert 1944 eksamens op 'n nasionale grondslag af. Ontleding toon dat eksamenuitslae 'n algemene op-en afwaartse neiging oor tien-jaar tydperke toon.

Sommige faktore wat eksamen-uitslae beïnloed blyk te wees die effek van hereksamen kandidate, swak begrip van die vakinhoud en groot verskille tussen mondelinge en skriftelike eksamenpunte.

Sedert die begin van 1984 is die eksamenstelsel aangepas om voorsiening te maak vir eksamenkomitees wat die vraelyste vir die verskillende vakke opstel en modereer. Terugvoer word ná elke eksamen aan dosente gegee deur 'n verslag oor die eksamenkomitee se bevindings en gevolgtrekkings.

Daar kan waarskynlik nooit 'n ideale stelsel vir eksamens op 'n nasionale vlak wees nie maar met die huidige stelsel poog die Raad om vir elke kandidaat 'n regverdige kans te gee.

\section{INTRODUCTION}

Examinations and examination results are an emotional issue and when the examinations are conducted on a national scale, with between 900 and 2000 candidates at a time, the problems involved are magnified proportionally.

The South African Nursing Council has conducted examinations since its inception in 1944, and although a variety of approaches has been used over the years, the features of national examinations are essentially unchanged - evidence of differences relative to local needs and resources; islands of expertise and excellence contrasting with areas of stagnation; differences in interpretation between examiners, tutors and students.

\section{RECURRING TRENDS}

Reference to Nursing Council statistics, shows that examination results have tended to follow a general upward or downward trend over consecutive periods of ten years, with peaks and dips occurring within the general trend of the ten-year span. The results of examinations conducted since 1975 in terms of the current regulations for the Diploma in General Nursing appear to be following the same pattern with a downward trend most evident at present, particularly in Anatomy and Physiology.

\section{SOME FACTORS INFLUENCING EXAMINATION RESULTS}

\section{Effect of re-entry candidates}

The effect on the pass rate of marks obtained by re-entry candidates is always evident, and is amply demonstrated in the analysis of results of recent Anatomy and Physiology examinations for the Diploma in General Nursing, shown in table 1 and table 2 .
Reference to the mark distribution in these examinations illustrated in figures $1-4$ underlines the observation that re-entry candidates do not perform as well as those entering for the first time.

\section{Grasp of subject-matter}

Reports presented over the past two years by the examination committees involved with these two subjects have indicated repeatedly that many candidates do not appear to have a grasp of the subject-

Table 1 Physiology examination: May 1985 Diploma in General Nursing

\begin{tabular}{|lccc|}
\hline & FIRST ENTRIES & RE-ENTRIES & TOTAL \\
& $(n=761)$ & $(n=342)$ & $(n=1103)$ \\
\hline Distinction & $3,0 \%$ & $0.3 \%$ & $2.1 \%$ \\
Pass & $79,2 \%$ & $41.8 \%$ & $67 \%$ \\
Fail & $17,7 \%$ & $57.9 \%$ & $30,2 \%$ \\
\hline
\end{tabular}

Table 2 Anatomy examination: June 1985 Diploma in General Nursing

\begin{tabular}{|lccr|}
\hline & FIRST ENTRIES & RE-ENTRIES & \multicolumn{1}{c|}{ TOTAL } \\
& $(n=833)$ & $(n=307)$ & $\left(n^{\circ} 1190\right)$ \\
\hline Distinction & $12,2 \%$ & $0,7 \%$ & $9,2 \%$ \\
Pass & $63,0 \%$ & $35,2 \%$ & $55,8 \%$ \\
Fail & $24,8 \%$ & $64,1 \%$ & $35,0 \%$ \\
\hline
\end{tabular}


matter and that candidates frequently do not read the questions properly. There is also a general tendency to rote-learn (inaccurately) as well as an inability to use the language of the subject, or even to distinguish between on, in, surround, lined and other terms used in anatomical descriptions. Examiners are frequently left in doubt as to whether candidates have formed any mental image of what they are attempting to describe.

Candidates are not penalised for grammatical or spelling errors, but it has nevertheless been observed that many candidates who demonstrate poor language use in their answers do not appear to have mastered the subject being examined. The Council is of the opinion that the symbols obtained for the official languages in the Senior Certificate examination are particularly important in the selection of students.

\section{Discrepancy between oral and written examination marks}

Another aspect which causes concern, and which also creates unfounded or unrealistic expectations is the serious discrepancy which is frequently shown between the oral examination mark submitted by the schools and the mark obtained in written papers. Obviously, there are candidates who can hardly be faulted in an oral examination but who have difficulty in conveying their knowledge in writing - but these are exceptions

The problem arises when all the candidates from a school obtain high oral marks, but fail to obtain even $40 \%$ in the written portion. Table 3 gives examples from two schools (among many) where candidates passed General Nursing Science and Art II in January 1984 by virtue of disproportionately high oral marks.

Lest it be thought that the problem is a small-scale one, it should be pointed out that an analysis carried out on one second-year examination held during 1984 revealed that had a sub-minimum of $40 \%$ been applied for the written portion of the examination the failure rate would have risen by some $30 \%$.
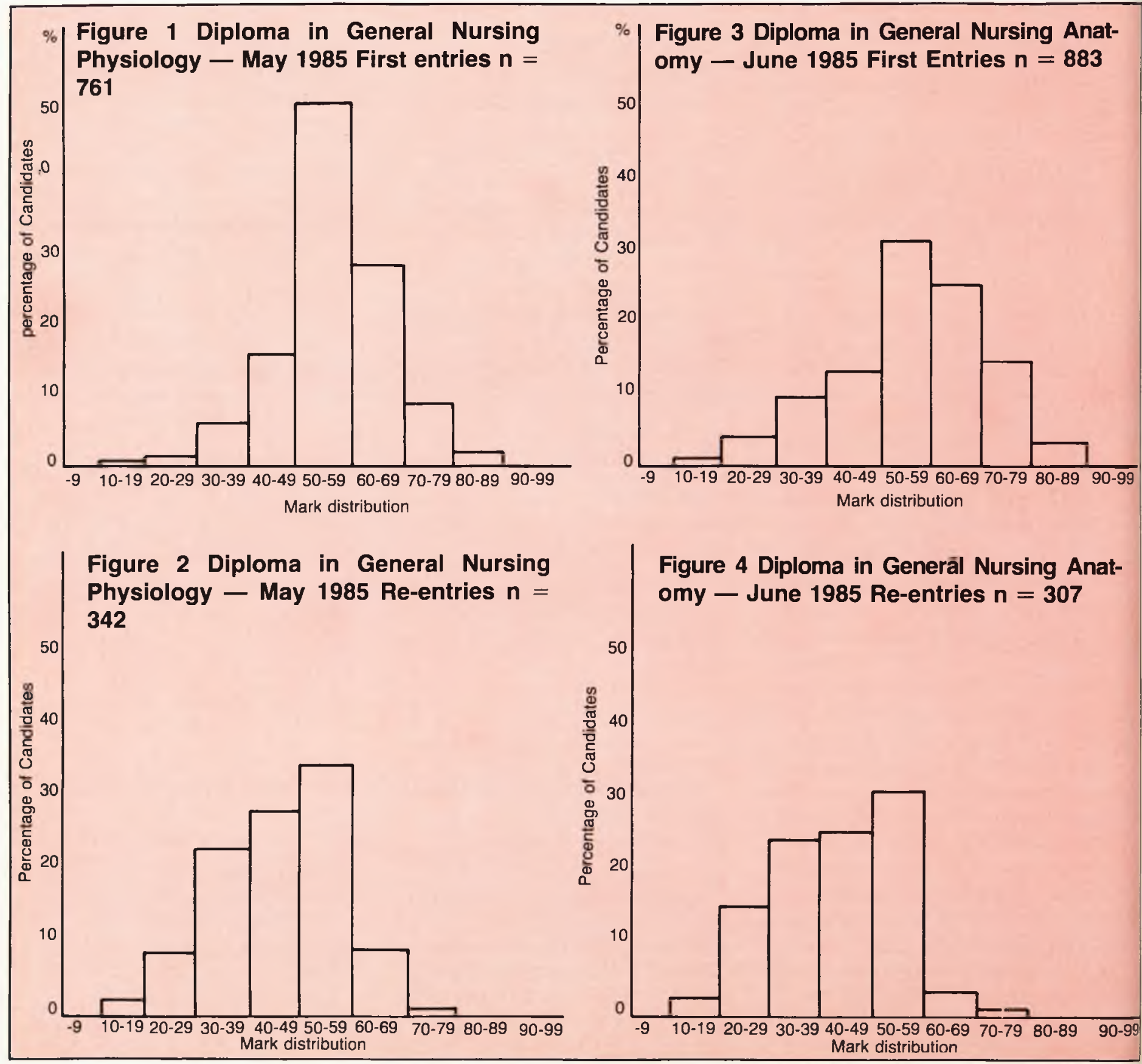
The information given here also explains how it comes about that the pass rate is generally higher in General Nursing Science and Art I and II than in Anatomy and Physiology - where there is no oral mark.

\section{THE EXAMINATION SYSTEM}

Since the beginning of 1984 , the examinations in the basic courses have been set and moderated by committees of experts in the relevant subjects.

Each examination committee is made up of tutors involved in teaching the subject, the number appointed for each committee being determined by the number of papers for the particular subject and by the average number of candidates. A member of the Council is appointed to each committee to act as consultant.

The examination papers and marking guides are drawn up by the committee which also moderates the candidates' scripts after these have been marked by sub-examiners. Sub-examiners are tutors, generally working in nursing schools, who are recruited and appointed by Council to mark the examination scripts. In general no sub-examiner marks more than 100 scripts.

Dissatisfaction is frequently expressed regarding the long wait between the date of examination and the publication of results. The Council has in excess of 100 examination centres in South Africa (including the self-governing national states and Bophuthatswana, Venda and Ciskei) and South West Africa. Scripts from the more remote centres may take two weeks or even longer to reach the Council after the examination.

All scripts arriving from examination centres are checked and sorted on arrival - this is necessary to ensure that all have been received and also because all the markers are not proficient in both official languages. The scripts are then despatched by post or by hand Table 3 Examples from two schools where candidates
passed by virtue of disproportionately high oral marks.

\begin{tabular}{|lll|l|}
\hline ORAL & PAPER I & PAPER 2 & RESULT \\
\hline 80 & 37 & 37,5 & Pass \\
76 & 36 & 38 & Pass \\
75 & 37,5 & 41 & Pass \\
96 & 29 & 34,5 & Pass \\
84 & 30,5 & 36 & Pass \\
90 & 50 & 37 & Pass \\
92 & 42 & 42 & Pass \\
86 & 35 & 40 & Pass \\
\hline
\end{tabular}

to the sub-examiners, who are situated in all the provinces. Postal delays occur frequently - it is on record that a parcel of scripts posted at Pretoria Central arrived at Silverton Post Office ten days later - a distance of some 10 kilometers.

After marking, the sub-examiners return the scripts to Council by post or by hand and, hopefully, in time to meet a specific deadline so that the examination committee can meet to moderate. Moderation usually takes a week, depending on the number of candidates.

It is important that all scripts should be available for the moderating which is done per candidate and not per individual script - this means that the scripts of each candidate are considered as a unit. If some are not available this means that the moderators are unable to complete their work in the time planned. If even one marker fails to return her scripts in time, the publication of results may be delayed for up to two weeks.

Constant efforts are made to recruit more sub-examiners - on the principle that a larger number of people, each marking a smaller number of scripts, will shorten the marking time, and thus facilitate timely publication of results.

A report prepared by the examination committee, reflecting their findings and recommendations, is circulated with the results whenever possible. Failing this, the report is circulated as soon as it becomes available. The purpose of the report is to provide feedback and guidance to tutors whose students have written the examination in question.

This procedure will obviously diminish in scope once the nursing college-university associations are fully implemented, and indeed, the Nursing Council will not conduct examinations for the Diploma in General Nursing, the Diploma in General Nursing and Midwifery, or the Diploma in General Nursing and Psychiatric Nursing, after the end of 1990.

However, it is anticipated that the examinations for the one-year courses in Midwifery and in Psychiatric Nursing will continue indefinitely as well as the course for enrolment as a nurse - and hence the committee approach in respect of these courses will be retained.

\section{CONCLUSION}

One wonders whether there will ever be a perfect examination not possible on a national scale to make adequate provision for all variables. However, in its implementation of the current system, the Nursing Council has attempted to ensure that candidates who have had the requisite preparation are given a fair chance of succeeding.

\section{REFERENCES}

The data set out in this article have been extracted from South African Nursing Council records. system anywhere - it is probably 